\title{
STUDI POLA OPERASI DAN KONSUMSI ENERGI POMPA KOLAM RENANG DI HOTEL RAMADA CAMAKILA DAN RAMADA BINTANG
}

\author{
I Gede Ginarsa ${ }^{1}$, I N. Satya kumara ${ }^{2}$, A. Ibi Weking ${ }^{3}$ \\ Program Studi Teknik Elektro, Fakultas Teknik, Universitas Udayana Denpasar - Bali \\ Email : gede.ginar@yahoo.co.id ${ }^{1}$, ins_kumara@yahoo.com², ignatius@unud.ac.id ${ }^{3}$
}

\begin{abstract}
Abstrak
Hotel Ramada Bintang dan Ramada Camakila memiliki kolam renang yang volume airnya hampir sama,akan tetapi ke dua kolam renang ini memliliki sistem pemompaan dan pengoperasian pompa yang berbeda. Ramada Bintang menggunakan dua buah pompa 5 Pk bekerja 12 jam sedangkan Ramada Camakila menggunakan dua buah pompa 1,5 Pk bekerja 24 jam, kondisi kedua kolam renang tersebut memiliki kejernihan dan kualitas air yang sama. Dalam penelitian ini dilakukan pengukuran energi listrik pada masing - masing pompa dan penghitungan kadar klorin, ph dan jumlah orang yang mandi pada masing- masing kolam renang. Hasil konsumsi rata-rata energi listrik perhari pada sistem pemompaan hotel Ramada Bintang adalah Rp. 106.080 sedangkan Ramada Camakila Rp. 74.640, jadi selisih konsumsi listrik selama setahun di kedua hotel adalah Rp. 10.579. 068 dengan perbandingan kualitas air yang sama.
\end{abstract}

Kata kunci : kolam renang, pompa,sistem pemompaan

\begin{abstract}
The Ramada Bintang and Ramada Camakila hotels have pools of nearly equal water, but these two pools have different pumping and pumping systems. Ramada Bintang uses two pumps 5 Pk works 12 hours while Ramada Camakila uses two pumps 1.5 Pk work 24 hours, the condition of both pools have the same clarity and water quality. In this study, electrical energy measurements were performed on each pump and calculated chlorine, ph and number of people taking bath in each swimming pool. The average electricity consumption per day on the Ramada Bintang hotel pumping system is Rp. 106,080 while Ramada Camakila Rp. 74,640, so the difference in electricity consumption for a year in both hotels is Rp. 10,579. 068 with the same water quality ratio.
\end{abstract}

Keywords : Swimming pool, pump, pumping systems

\section{PENDAHULUAN}

Hotel Ramada Resort Camakila yang terletak di jalan Pura Bagus Teruna Kuta, memiliki kolam renang yang volume airnya $250 \mathrm{~m}^{3}$ dan sistem pemompaannya di pompakan oleh dua buah pompa sentrifugal yang mana besarnya $1,5 \mathrm{pk} / \mathrm{satu}$ fasa dan beroperasi selama 24 jam, dan Hotel Ramada Bintang Bali Resort yang terletak di jalan Kartika plaza Kuta memiliki volume air $270 \mathrm{~m}^{3}$ untuk pemompaan airnya di pompakan oleh dua buah pompa sentrifugal dengan kapasitas pompa sebesar 5pk/tiga fasa dan hanya beroperasi selama $12 \mathrm{Jam}$ dari jam delapan pagi sampai jam delapan malam. Kolam renang Ramada Resort Camakila menggunakan dua buah filter air jenis pasir silica yang masing-masing memiliki kapasitas $300 \mathrm{~kg}$ atau $32 \mathrm{~m}^{3} / \mathrm{jam}$ dan Ramada Bintang Bali Resort menggunakan dua buah filter air jenis pasir silica yang masing-masing memiliki kapasitas $1200 \mathrm{~kg}$ atau $56 \mathrm{~m}^{3} / \mathrm{jam}$.

Dua hotel yang memiliki volume air kolam yang hampir sama dan memiliki sistem pemompaan dan pola operasi pemompaan yang berbeda merupakan hal yang menarik buat diteliti untuk 
mendapatkan informasi tentang kaitan antara pola operasi pompa, kapasitas dan konsumsi energi terhadap kejernihan air kolam renang.

Penelitian terdahulu Bhaskara 2009, yang berjudul, "Analisa kinerja pompa sentrifugal di fase 1 Pertamina DPPU Ngurah Rai berdasarkan hubungan daya listrik nyata dan debit keluaran yang terukur" telah terbukti bahwa perubahan parameter arus pada motor induksi akan mempengaruhi daya real, torsi dan debit fluida pada pompa. [1]

Menurut penelitian Amirullah 2009, dengan judul "Pengujian karateristik pompa susunan pararel dengan speifikasi berbeda" telah membuktikan bahwa apabila kapasitas pompa besar, akan diperoleh daya motor yang kecil hal ini dikarenakan arus listrik yang dihasilkan pompa besar dan hambatannya kecil. [2]

\section{KAJIAN PUSTAKA}

\subsection{Sistem pemompaan}

Kata Sistem berasal dari bahasa Yunani (sustēma) dan bahasa Latin (systēma). Pengertian dari kata sistem adalah sesuatu kesatuan yang terdiri dari sekumpulan atas elemen yang saling membutuhkan satu dengan yang lain. Pompa merupakan sebuah peralatan yang digunakan untuk mengubah energi mekanik menjadi energi gerak tekan pada zat atau cairan yang dipompa.

\subsubsection{Jenis-jenis pompa}

Jenis - jenis pompa dapat dibedakan menjadi :

1. Pompa perpindahan positif

Pompa perpindahan positif umumnya diketahui dari caranya beroperasi yaitu cairan diambil dari salah satu ujung ke ujung dan kemudian dialirkan secara positif pada setiap putarannya. Pompa perpindahan positif penggunaannya secara luas biasanya untuk pemompaan air dan dipakai juga untuk memompa fluida kental.

\section{Pompa Dinamik}

Pompa dinamik diketahui juga ari caranya beroperasi, putaran dari impeler yang mampu mengubah energi kinetik menjadi tekanan dengan kecepatan tertentu yang diperlukan untuk memompa zat tersebut.

\subsubsection{Filter Air Kolam Renang}

Filter air kolam renang berfungsi untuk menyaring dan menahan kotoran mikro yang mengalir menuju pasir silica. Filter kola ini dapat dicuci berkali - kai setiap hari sesuai tingkat kotoran yang ada di dalam kolam renang. Media pasir silica ini dapat bertahan bertahun - tahun tanpa harus diganti cukup dengan pemeliharaan yang rutin dan baik sesuai dengan prosedur perawatan. Filter kolam renang ini biasanya berbentuk seperti tangki dan terbuat dari bahan plastic ataupun fiber glas.

\subsubsection{Sistem Pemipaan Kolam Renang}

Pengertian Pemipaan merupakan suatu penyediaan air minum atau penyaluran air pembuangan di dalam sebuah bangunan. Kolam renang juga sangat memerlukan sistem pemipaan yang baik untuk kelancaran mengalirnya air dari pompa menuju filter dan kemudian dialirkan kekolam renang.

\subsubsection{Jenis-jenis dan macam-macam pipa}

Secara umum Pipa dibagi menjadi beberapa bagian diantaranya pipa tanpa sambungan las dan pipa non sambungan pembuatan. Banyak sekali dipasaran terdapat jenis -jenis pipa berdasarkan struktur bahan baku pembuatan pipa tersebut diantaranya pipa moli, pipa karbon, pipa pvc, pipa stailes, galvanis, dan berbagai macam pipa lainnya.

\subsection{Pengolahan Air}

Pengolahan air merupakan suatu sistem yang berfungsi untuk mengolah air dari yang kurang bagus menjadi bagus dan berkualitas standar yang diiginkan. Pengolahan air bertujuan mendapatkan hasil air yang siap pakai baik dikonsumsi ataupun di gunakan untuk keperluan sehari - hari. Hasil dari pengolahan air memiliki standar parameter seperti bebas dari bau, tidak berwarna, tidak mempunyai rasa.

\subsubsection{Unit Water Treatment}

Unit water treatment meliputi beberapa komponen yang sangat penting dalam proses penjernihan air kolam renang diantaranya meliputi :

\section{A. Sand Filter}


Sistem penyaringan ini terdiri dari media pasir silica yang di tempatkan dalam bak penampung baik berupa tangki maupun dalam bentuk tabung. Filter pasir ini berfungsi menghilangkan dan menyaring kotoran yang tidak bisa dilihat mata seperti keruhnya air, lumut, bau. Fiter ini biasanya memiliki daya tahan 3 - 4 dan dan harus sudah diganti.

\section{B. Karbon Aktif Filter}

Sistem penyaringan ini menggunakan media arang dan juga biasanya digunakan juga batu bara sebagai pengganti arang. Fungsi dari karbon iini adalah sebagai penyaring bahan organik, bau, warna dan juga sebagai penyring klor. Arang batok kelapa juga sering dipakai untuk filterasi ini dan filter jenis ini biasanya bertahan 1- 2 tahun tergantung kepekatan air yang di filter.

\subsection{Swimming Pool}

Swimming pool atau kolam renang merupakan sebuah konstruksi rancangan yang merupakan buatan manusia yang dirancang untuk diisi air yang akan dipergunakan untuk berenang, menyelam. Kolam renang juga biasnya digunakan sebagai sarana kebugaran jasmani maupun tempat rekreasi yang biasanya dilengkapi dengan fasilitas - fasilitas penunjang lainnya. Kolam renang biasanya dijernihkn dengan menggunakan klorin atau kaporit.

\subsection{Motor Induksi}

Motor induksi adalah motor listrik dengan arus ac yang sering digunakan di berbagai keperluan industri dan paling banyak digunakan dikeperluan sehari - hari. Motor induksi bekerja berdasarkan induksi medan magnet. Magnet ini menginduksi dari rotor ke stator, perbedaan medan putar antara medan putar dengan putaran rotor menimbulkan arus yang dihasilkan oleh kumparan stator.

\subsubsection{Konstruksi MotorInduksi}

Komponen motor induksi mempunyai 3 bagian utama yaitu :

1. Stator

Merupakan bagian yang diam dan tidak berputar, mempunyai belitan yang mampu menginduksi medan elektro magnetik ke kumparan putarnya/rotornya.
2. Celah

Celah adalah ruang udara tempat berpindahnya energi dari kumparan putar ke kumparan diam.

3. Rotor

Rotor adalah bagian atau komponen yang berputar/bergerak karena induksi magnet dari kumparan putar yang di induksikan kepada kumparan diam.

\subsubsection{Prinsip Kerja Motor Induksi}

Prinsip kerja motor induksi berdasarkan induksi medan magnet dari kumparan putar ke kumparan diam/stator. Jika kumparan stator motor induksi 1 -fasa, yang disambungkan dengan sumber tegangan 1-fasa, maka kumparan stator ini akan menghasilkan medan magnet yang berputar. Garis - garis gaya fluks yang diinduksikan dari kumparan diam akan memotong kumparan putarnya sehingga timbul gaya gerak listrik atau disebut juga tegangan induksi.

\subsection{Hubungan Motor dengan Pompa}

Jenis pompa kerja dinamis yang banyak dan paling sering digunakan adalah pompa sentrifugal jenis aliran campur. Pada pompa aliran campur ini arah aliran fluida merupakan campuran dari kombinasi antara aliran radial dan aksial dan keluar dari impeler dengan sudut antara 0 sampai 90 dari arah aksialnya.

\subsubsection{Perhitungan Energi listrik}

Untuk menghitung energi listrik pada masing - masing motor listrik digunakan rumus energi $: E=P . t$

Dimana $: E$ = Energi $(\mathrm{kWh})$

$P=$ Daya Listrik (Watt)

$t=$ Waktu (Jam)

\section{METODE PENELITIAN}

Penelitian dilakukan di Ramada Resort Camakila jalan Pura Bagus teruna legian Kuta Badung dan di Ramada Bintang Bali Resort jalan Kartika plaza Kuta Badung, Penelitian dilakukan pada tanggal 1 Septembersampai 1 Desember 2015

Data Primer, diperoleh dari penelitian dengan memasang $\mathrm{kWh}$ meter pada masing-masing pompa dan pengamatan langsung dilapangan serta dari wawancara 
dengan staff dan karyawan Ramada Resort Camakila dan Ramada Bintang Bali Resort

Data sekunder, Diperoleh dari masingmasing spesifikasi yang tertera pada fisik pompa kolam renang

Berikut adalah tahapan proses analisis:

1. Menentukan jumlah beban maksimum dengan menggunakan perhitungan daya secara teori dan kenyataan dilapangan dengan persamaan (1)

2. Membandingkan secara fisik kualitas air pada kolam renang dengan kapasitas yang lebih besar beroperasi 12 jam dan pompa dengan kapasitas lebih kecil namun beroperasi 24 jam

3. Menentukan penghematan waktu operasi dengan membandingkan hasil pengukuran daya dari kedua hotel

4. Menentukan sistem penyediaan pemompaan yang efektif dan lebih baik.

5. Menentukan energi dalam rupiah dengan tarip dasar golongan B-3 PLN tahun 2015. [5]

\section{HASIL DAN PEMBAHASAN}

Kolam Renang Ramada Resort Camakila memiliki volume air $250 \mathrm{~m}^{3}$, menggunakan pompa sentrifugal dengan motor induksi, setiap pompa memiliki sebuah filter air jenis pasir silica, menggunakan dua buah pompa masingmasing1,5pk satu fasa untuk sirkulasi airnya dan beroperasi selama 24 jam.Kolam renang Ramada Bintang Bali memiliki volume $270 \mathrm{~m}^{3}$, menggunakan pompa air jenis sentrifugal dengan jenis motor induksi. Menggunakan dua buah Pompa masingmasing 5pk tiga fasa untuk sirkulasi airnya dan kedua kolam renang mengunakan jenis filter air yang sama yaitu jenis filter pasir silika, pompa air kolam renangRamada Bintang yang mana otomatis hidup dan mati pompa diatur oleh sebuah timer.

\subsection{Data Konsumsi Energi Listrik Pada Pompa Kolam Renang Ramada Resort Camakila dan Ramada Bintang Bali Resort}

Dari penelitian yang dilakukan diperoleh data yang di buat dalam Tabel 1 berikut dibawah ini:

Tabel 1.Konsumsi kWh, $\mathrm{Ph}, \mathrm{Cl}$, kejernihan pada pompa kolam renang Ramada Bintang dan Ramada Bintang perjam

\begin{tabular}{|l|l|l|l|l|}
\hline \multirow{3}{*}{ Jam } & \multicolumn{3}{|l|}{ Bintang } & \multicolumn{2}{l|}{ Camakila } \\
\cline { 2 - 5 } & \multicolumn{4}{|l|}{} \\
\cline { 2 - 5 } & 1 & 2 & 1 \\
\cline { 2 - 5 } & $\mathrm{kWh}$ & \multicolumn{3}{l|}{} \\
\hline $00: 00$ & & & 1,3 & 1,3 \\
\hline $01: 00$ & & & 1,3 & 1,3 \\
\hline $02: 00$ & & & 1,3 & 1,3 \\
\hline $03: 00$ & & & 1,3 & 1,3 \\
\hline $04: 00$ & & & 1,3 & 1,3 \\
\hline $05: 00$ & & & 1,3 & 1,3 \\
\hline $06: 00$ & & & 1,3 & 1,3 \\
\hline $07: 00$ & & & 1,3 & 1,3 \\
\hline $08: 00$ & & & 1,3 & 1,3 \\
\hline $09: 00$ & 3,5 & 3,5 & 1,3 & 1,3 \\
\hline $10: 00$ & 3,7 & 3,7 & 1,3 & 1,3 \\
\hline $11: 00$ & 3,7 & 3,7 & 1,3 & 1,3 \\
\hline $12: 00$ & 3,7 & 3,7 & 1,3 & 1,3 \\
\hline $13: 00$ & 3,7 & 3,7 & 1,3 & 1,3 \\
\hline $14: 00$ & 3,7 & 3,7 & 1,3 & 1,3 \\
\hline $15: 00$ & 3,7 & 3,7 & 1,3 & 1,3 \\
\hline $16: 00$ & 3,7 & 3,7 & 1,3 & 1,3 \\
\hline $17: 00$ & 3,7 & 3,7 & 1,3 & 1.3 \\
\hline $18: 00$ & 3,7 & 3,7 & 1,3 & 1,3 \\
\hline $19: 00$ & 3,7 & 3,7 & 1,3 & 1,3 \\
\hline $20: 00$ & 3,7 & 3,7 & 1,3 & 1,3 \\
\hline $21: 00$ & & & 1,3 & 1,3 \\
\hline $22: 00$ & & & 1,2 & 1,2 \\
\hline $23: 00$ & & & 1,3 & 1,3 \\
\hline Total & 44,2 & 44 & 31,1 & 31,1 \\
\hline & & & & \\
\hline
\end{tabular}

Berdasarkan tabel diatas apabila dihitung dalam Rupiah maka harga pemakain listrik pompa kolam renang Ramada Bintang untuk ke dua buah pompa dengan persamaan (1-1) dengan tarif B-3 selama sehari adalah :

\section{$=44,2 \mathrm{Kwh} \times \mathrm{Rp} 1218 / \mathrm{kWh}$ \\ $=\operatorname{Rp} 53.040 \times 2$ (dua pompa) \\ $=\operatorname{Rp} 106.080$}

Sedangkan Ramada Camakila apabila dihitung dalam Rupiah dengan persamaan (1-1) maka harga pemakain listrik untuk ke dua buah pompa dengan tarif B-3 selama sehari adalah :

\section{$=31.1 \mathrm{Kwh} \times 1218 / \mathrm{kWh}$ \\ $=\operatorname{Rp} 37.320 \times 2$ (dua pompa) \\ $=\operatorname{Rp} 74.640$}

Dalam setahun diperoleh data pengukuran yang di buat dalam Tabel 2 berikut dibawah ini :

Tabel 2.KWh, Ph, Cl, Kejernihan setiap bulan dalam setahun kolam renang Ramada Bintang dan Ramada Camakila.

\begin{tabular}{|l|l|l|}
\hline \multirow{2}{*}{ Bln. } & \multicolumn{2}{|c|}{$\mathbf{k W h}$} \\
\cline { 2 - 3 } & Bintang & Camakila \\
\hline
\end{tabular}




\begin{tabular}{|c|c|c|c|c|}
\hline & $\begin{array}{c}\text { Pompa } \\
1\end{array}$ & $\begin{array}{c}\text { Pompa } \\
2\end{array}$ & $\begin{array}{c}\text { Pompa } \\
1\end{array}$ & $\begin{array}{c}\text { Pompa } \\
2\end{array}$ \\
\hline Jan. & 1281 & 1281 & 933 & 933 \\
\hline Peb. & 1196 & 1196 & 870 & 870 \\
\hline maret & 1281 & 1281 & 933 & 933 \\
\hline April & 1326 & 1326 & 964 & 964 \\
\hline mei & 1281 & 1281 & 933 & 933 \\
\hline juni & 1326 & 1326 & 964 & 964 \\
\hline juli & 1281 & 1281 & 933 & 933 \\
\hline Agus. & 1326 & 1326 & 964 & 964 \\
\hline Sep. & 1281 & 1281 & 933 & 933 \\
\hline Okt. & 1326 & 1326 & 964 & 964 \\
\hline Nov. & 1281 & 1281 & 933 & 933 \\
\hline Des. & 1326 & 1326 & 964 & 964 \\
\hline Total & 15512 & 15512 & 11288 & 11288 \\
\hline
\end{tabular}

\subsection{Hasil Perbandingan Konsumsi} Enerrgi Listrik Dalam Rupiah Kolam Renang Ramada Bintang dengan Ramada Camakila Selama Satu Tahun

Dari hasil penelitian yang dilakukan diatas didapatkan hasil konsumsi energi listrik masing - masing di hotel selama setahun, dimana di Ramada Bintang adalah:

$=$ Konsumsi energi listrik pertahun $\mathrm{x}$ jumlah pompa

$=15.512 \mathrm{kWh} \times 2$

$=31.024 \mathrm{kWh}$

Apabila dijadikan Rupiah maka :

$=\mathrm{kWh} \times$ Harga listrik perkWh

$=31.024 \mathrm{kWh} \times \mathrm{Rp} 1218 / \mathrm{kWh}$

$=\operatorname{Rp} 37.787 .232$

Konsumsi energi listrik di Ramada Camakila adalah :

$=$ Konsumsi energi listrik pertahun $\mathrm{x}$ jumlah pompa

$=11.288 \mathrm{kWh} \times 2$

$=22.576 \mathrm{kWh}$

Apabila di jadikan Rupiah maka :

$=\mathrm{kWh} \times$ harga listrik perbulan

$=22.576 \mathrm{kWh} \times \mathrm{Rp} 1218 / \mathrm{kwh}$

$=\mathrm{Rp} 27.497 .568$

Jadi selisih perbandingan konsumsi energi listrik antara Ramada Bintang dan Ramada Camakila adalah :

$=$ Rp. 37.787.232 - Rp. 27.497 .568

$=$ Rp. 10.289. 664
Dengan perbandingan kualitas air yang sama, berdasarkan data yang didapat diatas maka dapat dipilih pompa yang lebih kecil dan beroperasi selama dua puluh empat jam.

\section{KESIMPULAN}

1. Pada kolam renang Ramada Camakila sistem pemompaan kolam renangnya disirkulasikan dengan dua buah pompa 1,5 pk beroperasi 24 jam dan pada kolam renang Ramada Bintang sistem pemompaannya di operasikan oleh dua buah pompa 5 pk beroperasi selama 12 jam sehari.

2. Konsumsi rata - rata energi listrik perhari pada sistem pemompaan hotel Ramada Bintang adalah Rp. 106.080 sedangkan Ramada Camakila Rp. 74.640. Konsumsi listrik rata - rata perbulan di Ramada Bintang adalah Rp.3.230.136 sedangkan di Ramada Camakila adalah Rp. 2.348.547 jadi selisih konsumsi energi kedua buah hotel perbulan dalam rupiah adalah $\mathrm{Rp}$. 881.589. Sedangkan konsumsi listrik rata - rata selama setahun di Ramada Bintang adalah Rp. 38.761.632 dan Ramada Camakila adalah Rp. 28.182.564, jadi selisih konsumsi listrik selama setahun di kedua hotel adalah Rp. 10.579. 068 dengan perbandingan kualitas air yang sama.

\section{DAFTAR PUSTAKA}

[1] Arya Bhaskara. Analisa kinerja pompa sentrifugal di fase 1 Pertamina DPPU Ngurah Rai.Denpasar : Brawijaya; 2009

[2] Firdaus Amirullah. Pengujian karateristik pompa susunan pararel dengan speifikasi berbeda.Semarang : Diponegoro; 2009

[3] Muhammad Anand Ardhiansyah, Prasetyo Anggun Pribadi. Analisis kelayakan kolam renang FIK UNY berdasarkan standar kolam renang sehat. Yogyakarta :Universitas Negeri Yogyakarta; 2013 
[4] Nedianto. Perencanaan pompa sentrifugal untuk pemompaan air bersih dari bak penampung kereservoir pada fakultas pertanian Universitas IBA Palembang.Palembang :IBA; 2012

[5] http://www.pln.co.id/2015/05/plntarif-dasar-listrik, diakses tanggal 5 mei 2015. 